\title{
THE SINGAPORE FATWA AND IRSYAD ON NAZAR-NUZRIAH
}

\author{
Salbiah Ahmad*
}

\begin{abstract}
This article peruses the basis of doctrinal authority of the fatawa and irsyad on nazar-nuzriah (Ar. nadhr) issued by the office of the mufti of Singapore. This article suggests a rethinking on the matter in view of doctrinal authority.
\end{abstract}

Keywords: Fatwa, Nadhr, Singapore Muslim law of Inheritance and Succession, Singapore Administration of Muslim Law Act.

The Singapore Administration of Muslim Law Act (AMLA) is one of the earliest pieces of legislation on the administration of Islamic law in Singapore and Malaysia. It was drafted by the late Prof. Emeritus Ahmad bin Mohd. Ibrahim when he was State Advocate General of Singapore (1959-1963). The provision on nazar (Ar. nadhr) under Section 60 AMLA has its corresponding and similarly worded provisions in the Malaysian state administration of Muslim law enactments in the various states of Malaysia.

\section{The Historical Dhevelopment of the Nazar}

The nazar is perhaps one of the earliest contractual forms used by Muslims. History shows that obligations between early Muslims were established by oaths (i.e. to swear by God's name to do something or to prove the correctness of something ${ }^{1}$ affirmatively or negatively). A classic example of the oath is the $b a$ 'iah or oath of allegiance owed by the people and/or troops to the caliph. A breach of the $b a$ 'iah is seen as a breach of the covenant with God. Nazar, however, originates as an oral vow with $\operatorname{God}^{2}$ a breach of which would result in the penalty of expiation or kaffarah. ${ }^{3}$ Although in our contemporary age, expiation may seem irrelevant, in the $10^{\text {th }}-11^{\text {th }}$ centuries such breaches of covenants aroused great moral outrage. ${ }^{4}$

The requirement of registering public nazar during the Ottoman period (1299-1923) allows us to glimpse the practice and development of this type of oath. ${ }^{5}$ The earliest Ottoman fatwa collections to discuss the nazar emerged in the $17^{\text {th }}-18^{\text {th }}$ centuries. By-and-by, Ottoman jurists developed the customary practices surrounding the vow into a specific contractual device explained in the 
fatawa. These fatawa discussed whether the nazar as a religious/moral obligation could be transformed into a legal obligation. The chief mufti of Istanbul, the shaykh al-Islam, Catalcali Ali Efendi (1674-1686), for instance, like other preOttoman jurists, did not allow the transformation of religious obligations into legal obligations and the criminalisation of sin. He especially frowned upon the state's expansion of its authority into the domain of God. In particular, during this period there was a growth in state-related/state-inspired vows, where sums of money and property were pledged to the state. ${ }^{6}$ In 1682, for example, in the town of Bosna Saray (Sarajevo), the Shariah judge and his deputy were both attacked and left for dead. The townspeople then pledged to pay the state 40,000 gold coins and to hand over the heads of those responsible, should a similar mischief recur. The nazar in this case was sealed by a column erected in a public spot. Likewise, in 1708 a group of non-Muslims went to the court of 'Ayntab (Gaziantep) with one of their co-religionists, claiming that he had meddled in their affairs. They wanted him to take a nazar that, in the event that he interfered in their affairs again, he would pay a sum of money for repairing the state-run court building. He agreed and the nazar was recorded.

But, a fatwa itself is not a source of law. ${ }^{7}$ It determines the rules that apply to a case in question. It is a single verdict for a single case. Neither is a fatwa as the opinion of a single mufti/jurist, unassailable. ${ }^{8}$ It is thus possible to issue different fatawa on the same issue, depending on what is presented as a conundrum from the persons requesting the fatwa from the mufti/jurist.

Nevertheless, the fatawa of prominent muftis, as acknowledged by the community, have frequently undergone a process of generalisation. While omitting legally irrelevant facts and personal details, the contents of these specific fatwa have been abstracted into legal formulas. These abstracted fatawa have then been collected with others of the same type, the principles or norms underlying them entering the literature of the legal school as principles that could be used as a basis for subsequent fatawa. In other words, specific fatwa have been transformed from the personal view of a jurist into an authoritative legal interpretation or understanding of a legal rule. ${ }^{9}$

This evolution of the fatwa gradually resulted in the development of the nazar into an agreement between an individual and God. In addition, a third party could be specified as a beneficiary of a vow, thereby committing the vowtaker to a certain course of action in relation to that beneficiary. ${ }^{10}$ The nature of the obligation could vary according to the pledged act. If the pledged act was not religiously mandatory (repair the court building example supra), its fulfillment would be optional and the vow-taker could opt for expiation. ${ }^{11}$ The prospective beneficiary may not demand fulfillment because the pledge is with God. Nazar that creates a religious obligation, on the other hand, such as fasting, prayer 
or alms-giving, are considered irrevocable and must be fulfilled - though not because of nazar per se, but because they are obligatory by independent Shariah evidence.

\section{Nazar under AMLA in Singapore}

AMLA has two main provisions on nazar, as contained in its Section 2 and Section 60.

Section 2 sets out the meanings of a nazar and a public nazar. Thus, nazar is "an expressed vow to do any act or to dedicate property [emphases added] for any purpose allowed by the Muslim law", and nazar 'aam means "a nazar intended wholly or in part for the benefit of the Muslim community generally or part thereof, as opposed to an individual or individuals."

By thus defining both private and public nazar/nazar 'aam, AMLA serves to "regulate" the practice. The state is also able to intervene in the case of public nazar/nazar 'aam under the circumstances set out in Part IV AMLA (i.e. where property is involved).

AMLA also restricts the disposal of property under the private nazar or the public nazar/nazar 'aam to the faraid and one-third bequest rule. In other words, AMLA reinforces the juristic consensus on the faraid one-third bequest rule, whether made by a will or by nazar.

Section 60(1) prohibits any will or death-bed gift effected by a "wakaf or nazar made after $1^{\text {st }}$ July 1968 ", of "the excess beyond one-third." This stipulation correctly sets out the faraid one-third bequest rule in Islamic jurisprudence. The cut-off date of $1^{\text {st }}$ July 1968 is intended to be an administrative measure and does not change the one-third bequest consensus.

In Section 60(2) and (3), AMLA provides a specific set of conditions for a valid nazar in Singapore. S.60(2)(a), for example, reads:

"Every wakaf khas or nazar made after 1 $1^{\text {st }}$ July 1968 shall be null and void unless -

(a) the President ${ }^{12}$ shall have expressly sanctioned and validated or ratified the same in writing in accordance with the Muslim law; or

(b) it was made during a serious illness from which the maker subsequently died and was made in writing by an instrument executed by him and witnessed by 2 adult Muslims one of whom shall be a Kadi or Naib Kadi."

S.60(3) reads: "If no Kadi or Naib Kadi is available as described in subsection (2)(b), any other adult Muslim who would not have been entitled to any beneficial interests in the maker's estate had the maker died intestate shall be a competent witness." 
S.60(2) expressly states nazar in general, and so is not limited to nazar 'aam or to the public nazar. This is a drafting/legislative oversight as private nazar should not be subject to the same rigorous rules regarding the Majlis Ugama Islam Singapore (MUIS) sanctions in S.60(2) and (3). However, it is the writer's opinion that S.60(1) applies to the private nazar via the consensus of the ages.

AMLA sanctions the nazar as a form of dealing while adding further qualifications to the private nazar in S.60(1). For example, although nazar is a dealing and a form of contract, it is not an ordinary contract. Nazar is an agreement between an individual and God. The beneficiary is not therefore entitled to demand its performance. If the nazar is not performed, the person who makes the nazar has to do kaffarah (expiation) as explained before. The only obligation is that of the maker of the nazar. The doing of nazar is not wajib (obligatory) or haram (forbidden). It lies in between these two values.

If the nazar contains an irrevocable religious pledge, on the other hand, like performing umrah, ${ }^{13}$ the maker of the nazar has to perform it and cannot opt for expiation. If the maker of the nazar dies before its performance, his/her heirs are obliged to perform the religious obligation on his/her behalf.

\section{MUIS Fatwas on Nazar-Nuzriah}

MUIS has, through the office of the mufti, issued fatawa on nazar-nuzriah and the irsyad (guidelines) on nuzriah with its accompanying "nazar statement". According to Mohamed Fatris Bakaram, in his thesis on ifta ${ }^{14}$ (the act of issuing fatwa), MUIS has issued three fatawa on nazar-nuzriah. These were issued in the traditional format, where only the outcome is written down.

\section{Fatwa 1:}

Facts: The petitioner had made a will instructing that his estate be distributed according to the Shafi'i school. He also made a nuzriah indicating that a portion of the estate he inherited from his late father was to be given by way of nazar to all his nephews and nieces in equal shares.

The Question: Whether the will and nuzriah are valid?

The Decision: Both the nuzriah and will are valid according to the Shafi'i school.

\section{Fatwa 2:}

Facts: A four-room Housing Development Board (HDB) flat was bought by the petitioner using his parents' names on the title. He was not allowed to purchase a second HDB apartment under HDB regulations. The apartment was intended for the use of his parents in their lifetime. It was not a gift. He does not want the property to be included as faraid property of the parents upon their deaths. 
The Question: How can he devise a will to ensure that the property remains his property under Islamic law?

The Decision: The petitioner can realise his intention by making a letter of nuzriah.

\section{Fatwa 3:}

Facts: The petitioner, a widow, wanted to pass her property on to her two daughters and she made a will to that effect.

The Question: How can she ensure that in the will that the property will be inherited by her two daughters upon her death?

The Decision: By using the nuzriah, the property is considered to have been given to the two daughters during the petitioner's lifetime.

\section{The Basis of the MUIS-Nuzriah}

In his thesis supra, Bakaram stated that the MUIS legal committee ruled to accept nuzriah on the authority of al-Haytami (1503-1566). This individual, who was based in Egypt and Mecca, was an excellent scholar of the Shafi'i school such that, at the age of just 20 , he was given permission by his teachers to issue his own fatawa and teach. ${ }^{15}$ According to the minutes of the MUIS legal committee, al-Haytami's best-known work, the Tuhfah al-Muhtaj li-Sharh al-Minhaj, a commentary on the Minhaj et-Talibin of al-Nawawi of Damascus (1233-1276), was utilised in their decision making. On the basis of it, they concluded that: "According to al-Haytami, the enforcement of nuzriah can be deferred to a date specified by the person making the nazar wheich can be anytime between the date the nuzriah is made, to a maximum of 3 days before death due to illness, or one hour before sudden death." 16

In the current author's view, however, in this context the legal committee's reference to al-Haytami's commentary on Minhaj et-Talibin is problematic. Although this text contains a chapter on nazar, ${ }^{17}$ there is no paragraph (or anything similar) on nuzriah. It is possible that reference is nonetheless made to al-Haytami as an "authority" because his work is a commentary on the famed Minhaj et-Talibin, which has been a highly-regarded work on the Shafi'i school since the $16^{\text {th }}$ century. Al-Haytami, however, is a later-day jurist compared to al-Nawawi; his personal commentary on al-Nawawi's work is not the same as saying that it is al-Nawawi's work. ${ }^{18}$ This, in my view, creates a problem in establishing the doctrinal authority of the MUIS ruling on nazar-nuzriah.

Although al-Haytami, as a jurist/mufti and in his capacity as mussannif (compiler author-jurist) ${ }^{9}$ would have included in his sharh (commentary) emerging concerns or changing conditions not pondered in al-Nawawi's time, al-Haytami's 
view would nevertheless represent only a single view of a single jurist in his age. Moreover, his observations should not be mistaken for a fatwa. Even if it were a fatwa, it is not a source of law; as mentioned, only the fatwa issued by the first generation of the Prophet's companions (sahaba) could carry such weight. ${ }^{20}$

Certainly, there are many differing views on this subject. Ibn Rushd (the "Averroes" of Andalusia Muslim Spain, 1126-1198), for example, in his compendium of all the schools, the Bidayatul al-Mujtahid wa Nihayat alMuqtasid (or The Distinguished Jurist's Primer), has a short treatment of the nazar of a person who gives away his property in its entirety. ${ }^{21} \mathrm{~A}$ consensus of opinion allowed such a nazar, but Imam Malik allowed the nazar subject to a one-third rule. This difference in opinion was traced to a hadith relating to Abu Lubabah, who sought God's forgiveness and decided to give all his wealth in charity. The Prophet, however, said that a third is more than enough. By contrast, there is no reference to any view on the postponement of the implementation of a nazar in a near-death situation. This is also the case in the Ottoman Hanafi compendium, the Mejelle.22

\section{The Hadramawt Fatwa on Nuzriah}

The MUIS legal committee also referenced a fatwa on nuzriah contained in the Bughyat al-Mustarshidin, a fatwa compilation by Syed Abd al-Rahman Ba'alwi, the mufti of Hadramawt. This fatwa evinces that the nuzriah is a practice "of some segments of the Shafi'i school....in Hadramawt, Yemen." ${ }^{23}$ Bakaram opines, however, that the use of the nuzriah "in other Muslim jurisdictions is not known," making the views in Hadramawt "not a position of consensus." 24 Bakaram further adds that the practice should only be acceptable "when strict observance of the rules of fara'id and the prerequisites of wasiyyah is likely to cause greater harm." 25

I would also add caution to the Hadramawt practice. We do not know the circumstances in Hadramawt, or the situations in which the particular nuzriah was used and/or contested. In other words, because we are dealing with a fatwa, we are dealing with something that is context specific. Understanding this context becomes doubly relevant when we consider that the fatwa has not yet evolved into a principle of the school - especially as the nuzriah situation has implications on the one-third bequest rule of faraid, which enjoys the consensus of all ages.

\section{The Irsyad}

According to the mufti of Singapore's website, irsyad is "a religious guidance issued by the office of the mufti which aims to address the various issues related 
to Islamic practices and perspectives on current development." ${ }^{26}$ The irsyad is therefore distinguished from the fatwa in that the latter is understood under the AMLA as a legal opinion issued in answer to an individual or group or at the request of a judge on a difficult point of law. As religious adviser under MUIS, the mufti of Singapore is an ex-officio member (S.30(3)) empowered to advise the President of Singapore on the "Muslim religion" and "to administer matters relating to the Muslim religion and Muslims in Singapore" (S.3(2a) and (2b)).

\section{The MUIS Irsyad on Nuzriah ${ }^{27}$}

The nuzriah-irsyad stipulates that nuzriah is "making nazar." By this categorisation, it imports the characteristics of a nazar into the settled jurisprudence. Moreover, the irsyad sets out the conditions of a nuzriah and sets out a sample of a "nazar statement."

In this sample, the person who makes the nazar inter alia seeks "to relinquish all ownership of the house and give it to the person that is mentioned in (the) nazar without any obligations" and "the transfer is enforceable three days before my death (if it is due to sickness) or an hour before my death (if it is due to accident or sudden death)." A further declaration states that the nazar is made "according to the rules and conditions set by Islamic law."

In reiteration, legally the nazar is an agreement between an individual and God. The beneficiary is not entitled to demand its performance. If the nazar is not performed, the person who makes the nazar has to do kaffarah (expiation), as explained before. However, for the sake of argument, we may like to consider whether the nazar statement is intended to operate as (a) a gift inter-vivos or (b) a bequest taking effect upon death.

The Islamic law on gifts inter vivos allows any part or the whole of a property to be divested. Moreover, the property so divested is not part of faraid. In a bequest, however, the value of the property cannot exceed the one-third rule, unless all faraid sharers consent to it after the death of the testator. This is settled law by the consensus of the jurists. In this context, the MUIS-drafted nazar statement is complicated. If the disposition in favour of an heir is made in a situation of "death-illness" or mard-ul-maut, where there is an apprehension of death due to illness, such a disposition is invalid if the other heirs do not approve of it.

In the case where a bequest is made and the testator dies suddenly (not being in a situation of mard-ul-maut), jurists have considered the following:

- If the donor dies before the recipient has "taken possession" (i.e. before a title is perfected under the law), the option lies with the faraid sharers. The gift is void before taking possession because taking possession is a condition for its completion. 
- If title is not perfected before death, the gift operates as a bequest and the one-third bequest rule applies as it would in a will, unless all faraid sharers agree to the bequest exceeding one-third.

- If the gift is made to a faraid heir, this again requires the consent of all faraid sharers.

- If the gift is perfected and the donor survives the illness, the donor cannot revoke the gift, while a testator can always revoke his will before death. ${ }^{28}$

The irsyad is guidance for the faraid sharers to consider the wishes of the deceased. It is a statement of good intention. I believe the irsyad on nazarnuzriah may have been issued in the context where the immediate family of the deceased, namely his spouse and children, are unceremoniously routed from the family home by faraid sharers and as "good Muslims", the sharers are invited to consider the wishes of the deceased who had executed a nazar statement.

\section{Concluding Remarks}

In summation, there are several factors affecting the operation of nazar-nuzriah in Singaporean Muslim law.

\section{AMLA prohibitions:}

To be valid under AMLA, private and public nazar (if it is dedicated to property) has to comply with the sections in PART IV of AMLA. On the face of it, the nazar statement may run aground under AMLA and fail to constitute a "legal" document. It may stand as "guidance" but can cause some confusion as AMLA applies as a rule.

The references to al-Haytami's view and the Hadramawt fatwa:

Al-Haytami's view of a nazar-nuzriah is the single view of a jurist living in a particular context. Any "relating-back" to al-Nawawi's work is problematic as al-Haytami's specific view is not included in al-Nawawi's compendium of the Shafi'i school. Nor is it included as a Shafi'i position elsewhere, or mentioned as a variant/minority opinion in the compendium of all the schools by Ibn Rushd.

If indeed there is a clear opinion which "relates back", then we need to understand the positions of the other schools' jurists to it. This would be a fair description of the process to be undertaken in a case of competing fatawa or in the case of one fatwa and a competing opinion of an expert on Shariah. 
Concerning the practices of "some segments" of Hadramawt society, it would be necessary to revisit the context in which the Hadramawt fatwa emanated. Moreover, this fatwa is also a single fatwa issued by a single jurist. The context therefore becomes relevant, particularly as this fatwa has not yet evolved into a principle of the school, and especially as the nuzriah situation has implications on the one-third bequest rule of faraid.

\section{The court as adjudicator in a dispute over nazar-nuzriah:}

When a matter reflects a religious observance ('ibadah), its resolution is left to personal observation and individual conscience. When the matter is one of conflict between the rights of individuals, however, it is a civil transaction (mu'amalat) and judges are called upon to determine the facts on the basis of court room evidence.

Significantly, therefore, the "courts" in S.2 AMLA are arguably not the proper place to enforce good conscience upon Muslims. In a court room, the judge would have to consider the facts of the case and the evidence before him, before making a decision based on established figh. Moreover, a judge would first choose to reach a decision based on established fiqh reached by consensus. It would be an uphill task to convince a judge to adopt a minority or variant opinion in the face of juristic consensus. AMLA would also apply to the nazar-nuzriah when a matter goes to court.

\section{Policy Recommendations}

- It might be useful for MUIS to commission a study of the nazar-nuzriah in view of the latter's supposed general applicability. This is particularly so given the lack of clarity in the nuzriah/nazar-statement, as compared to how nazar is understood in the traditional sources.

- It is inadequate in this day and age of meticulous scholarship to merely refer to a paragraph in al-Haytami's work, without understanding its context (i.e. the consensus of the jurists, gifts inter vivos, or the one-third bequest rule in Muslim inheritance and succession). I would suggest that a consultation be made with lawyers who practice Muslim law and a selected team of public intellectuals with relevant expertise, to frame new research questions capable of setting nazar on a better footing.

- Future research may also be expanded to study the urf of Hadramawt, as this could showcase how the Hadramawt fatwa is practiced. If it is a proper $u r f$, it should survive to this day in the practices of the community. 
This research should remain possible, despite the conflict in Yemen, as the institutions of the mufti and universities are intact.

- The Bughyat al-Murtashidin fatwa compilation is referenced under the Indonesian Kompilasi Hukum Islam. Future research might therefore be further expanded to investigate the uses of the nazar and/or the nazarnuzriah in that country. There are no known cases in Malaysia of the nazar-nuzriah. Similar AMLA state statutes in Malaysia incorporate the Singapore AMLA provisions on nazar and nazar 'aam, almost verbatim.

Only after the grey areas are revisited and necessary clarifications are made, can we move forward with how the AMLA provisions on nazar-nuzriah can be applied. In a final note, I hope that the legal fraternity, especially lawyers with an AMLA practice, will consider collaborating with MUIS and the academic community to convene periodic conferences to discuss important matters pertaining to Muslim family law and the Muslim law of inheritance and succession.

\section{Notes}

* Salbiah Ahmad is a member of the UN Women roster of CEDAW experts. She has experience in legal matters, teaching at the university, and participating in national and regional NGOs, spanning more than 20 years.

1. The oath or al-yamin survives today as a type of proof in Islamic law of evidence.

2. The manuals of the law schools usually contained a chapter on nazar, sometimes under the heading "Book of Vows" and/or "Book of Oaths".

3. The Qu'ran stipulates the nature of expiation in al-Ma'idah, 5:89. Expiation could take the form of feeding or clothing ten poor people, freeing a slave or fasting for three days. Jurists developed the details of observing this commandment and choosing the type of penalty.

4. Roy Mattahadeh (1980) Loyalty and Leadership in Early Islamic Society. Princeton University Press: Princeton, NJ. at pp. 46-7.

5. Information on the Ottoman practice in this note is from a well-researched paper by Hulya Canbakal, "Vows as Contract in Ottoman Public Life (17-18 Centuries)", (2011) Islamic Law and Society, Vol. 8 Issue 1, pp. 85-115.

6. Ibid, at p. 100. Muftis traditionally form part of civil society.

7. Mohammad Hashim Kamali (1989) Principles of Islamic Jurisprudence. Pelanduk Publications: Selangor. See Chap.11 on The Fatwa of Companion. pp. 297-308.

8. By contrast, the fatawa of the Companions commanded a higher status due to the special standing of the Companions themselves, as spokespersons and interpreters of the Sunnah of the Prophet. They carried a strongly persuasive, 
yet still not binding, authority (unless there is independent support for their decisions in the Qur'an or an explicit hadith).

9. Wael B. Hallaq (2009), Sharia: Theory, Practice, Transformations. Cambridge University Press, NY at pp. 176-83; Knut S Vikor (2005) Between God and the Sultan: A History of Islamic Law. Oxford University Press, New York. at p. 164.

10. Canbakal op. cit. at p. 88 .

11. ibid. Canbakal argued that the pledged act of repairing the courthouse and cleaning up the river are charitable acts of public importance and, like the waqf, has to be fulfilled.

12. The President here connotes the President of the Singapore Majlis Ugama Islam.

13. Umrah is not the obligatory pilgrimage and so can, and unlike the Hajj pilgrimage, be subject of a nazar.

14. Mohamed Fatris Bakaram, Theories of ifta in Islamic law with special reference to the Shafi'i school of law and their application to contemporary Singapore. Thesis submitted to the University of Birmingham for the degree of Doctor of Philosophy, 2009, pp. 189-90. Bakaram is the current mufti of Singapore. The fatawa were issued before his time as mufti.

15. Ahmad bin Mohamed Ibrahim (1965) Sources and Development of Muslim law. Malayan Law Journal: Singapore. at p. 124.

16. op. cit. at p. 189.

17. Nawawi's Minhaj-Et-Talibin (A manual of law under the Shafi'i school) (1977 reprint). Law Publishing Company: Lahore, Pakistan. The chapter on vows "nazar" is from pp. 495 to 499.

18. Wael B Hallaq refers to al-Nawawi's statement in Al-Majmu, that he (al-Nawawi) does not exclude any of Shafi'i's opinions or other opinions even if they happen to be weak or insignificant. See Wael B Hallaq, 'Can the Shariah be Restored?', in Yvonne Y. Haddad eds. (et al) (2004) Islamic Law and the Challenges of Modernity. Altamira Press: Walnut Creek, pp. 21-23.

19. Wael B Hallaq, 'The author-jurist and legal change in traditional Islamic law,' Recht von de Islam 18 (2001), pp. 31-75 at p. 35. Hallaq includes jurist-mufti Ibn Hajar al-Haytami (1503-1566) of the Shafii school, in this category.

20. Mohammad Hashim Kamali (1989) Principles of Islamic Jurisprudence. Pelanduk Publications: Selangor. pp. 297-308.

21. Ibn Rushd, The Distinguished Jurist's Primer. Vol 1. trans. by Imran Ahsan Khan Nyazee (2000). The Centre of Muslim Contribution to Civilisation. Garnet Publishing Ltd: UK at pp 513-515 on Book of Nudhur (Vows). The Bidayat alMujtahid is a compendium of all schools including the Shafii school.

22. Mejelle al Ahkam I Adliye (The Ottoman Islamic Civil Code developed between 1869-1876). The Code deals with the "gift of a sick person" (trans.) in four articles reiterating the consensus. English translations of this are available. The Code was and still is a judicial reference of the Hanafi school of law.

23. Bakaram. op.cit. at p.189.

24. ibid at pp. 191-2.

25. Ibid at pp. 193.

26. www.theofficeofthemufti.sg/Irsyad/Index.html, accessed 2015.12.27.

27. www.officeofthemufti.sg/Irsyad/nuzriah_eng.html, accessed 2016-01-01. 
28. Laleh Bakhtier (1996) Encyclopedia of Islamic laws: A Compendium of the Views of the Major Schools. KAZI Publications: Chicago. The compilation is based on two Arabic sources: al Fiqh alal madhab al-arbaah and al-Fiqh alal madhab al-khamsa. The schools considered are Hanafi, Hanbali, Shafi'i, Maliki and Jafari (see pp. 363-368). A compendium or manual is an abbreviated form of fiqh, including ijma-consensus, jumhur-majority and variant opinions. Compendiums like Minhaj et-Talibin (Shafi'i), the Bidayatul al-Mujtahid (all schools) or the Ottoman Mejelle (Hanafi) are standard references. 